\title{
Evaluation on the Synergistic Effect of Production, Sales and R \& D after Enterprise's M \& A
}

\author{
Xin Mei ${ }^{1, a}$, Yun-Mei $\mathrm{Li}^{2, \mathrm{~b},{ }^{*}}$, Yang $\mathrm{Hu}^{3, \mathrm{c}}$, Yong-Cheng Zhu ${ }^{4, \mathrm{~d}}$ \\ ${ }^{1,2,3,4}$ Center for Industrial Policy and Management Research, Wuhan University of Science and \\ Technology,123-116-2,Gangdu Garden, Qingshan District, Wuhan, China \\ axinmo1234@126.com, 'lymwust@163.com \\ ${ }^{*}$ Corresponding author
}

Keywords: Enterprise's M \& A (mergers and acquisitions), Synergistic effect of production, Sales and R \& D (research and development), Evaluation system, PAN model.

\begin{abstract}
In the current economic environment, synergy is becoming a trend of business management and research on evaluating synergistic effect of enterprises is in need. So the author innovatively established an evaluation model of production, sales and R\&D synergistic effect from the positive and negative synergistic effect aspects. In the consideration of enterprises' stakeholders' interests, enterprises' risks and development prospects, 6 primary indexes and 34 secondary indexes were selected with the method of questionnaire survey. Then AHP method and experts scoring are adopted to design the scoring criteria and calculate the weight of indexes. Finally an evaluation model named PAN was established to evaluate the production, sales and R\&D synergistic effect. The established model can help enterprises identify their advantages and disadvantages, and it plays an important role in optimizing the enterprises' synergistic management.
\end{abstract}

\section{Introduction}

In current economic environment, it's difficult for enterprises to complete all the processes on the product value chain, such as raw material sourcing, product designing, product developing, products selling relying solely on their own strength[1]. Therefore, some enterprises attempt to accomplish the business processes of production, sales and R \& D (Research and Develop) by M\&A to achieve the business goal of stable development in long-term. Production, Sales and R \& D Synergy is a new management method with information technology on the basis of "synergy theory" in current business environment[2]. Research of production, sales and R \& D synergistic effect and evaluation system is beneficial for enterprises to improve the management pattern including response to changing market conditions rapidly, reduce production cost, improve the quality of products etc[3].

\section{Literature Review}

\section{Synergistic Effects}

Synergistic effects were proposed firstly by the American scholar Ansoff in the 1960s. He pointed out that synergy consisted of ROI (rate of investment) and super-additivity, thus enterprises' overall value may be greater than the sum of parts' value in synergy[4]. Japanese scholar Itami proposed that the true cause of synergy is not complementary synergistic effect but the enterprise's unique resources, such as trademarks, customer recognition, corporate culture etc. They bring more lasting and irreplaceable competitive advantages to enterprises because of the inimitable synergistic effect. Sirower claimed that synergy must be considered in a competitive environment. And it should be the part which the benefits of enterprise after M\&A exceed the sum of acquiring enterprise and the acquired enterprise when they were both as independent[5].

Chinese scholars mainly research the synergistic effect from the aspects of finance, intangible assets, operation and management, etc. Feng expounded the importance of financial synergy to enterprises' synergistic management and value creation after analyzing the relationship between the financial control and financial synergy[6]. Liu deemed from the intangible assets aspect that the expansion of qualified intangible assets like the brand superiority, technology proprietary, and enterprise culture, contributes to synergy after $M \&$ A[7]. Yang analyzed the influence factors of synergy from the innovative strategies and technical capabilities[8]. 
In summary, existing studies on synergistic effect consist of two parts: internal enterprise synergistic effect and the synergistic effect between enterprises[9]. And most scholars only pay attention to the positive effect of synergy, ignoring the existence of negative synergistic effect. And research about production, sales and R \& D synergistic effects after M\&A is limited. Therefore, the author proposed a new direction, evaluating synergistic effect of production, sales and R\&D after M\&A from both positive and negative aspects. It's the innovation and value of this study.

\section{Synergistic Effect Evaluation Model}

There are two main evaluation models of synergistic effect [10]. One is the net present value evaluation model, the other is M\&A synergies model. And these two models mentioned have their own defects. The net present value evaluation model can't reflect the enterprise's actual operating conditions and it ignores enterprises' social responsibilities. As for the M\&A synergies model, the calculation result has a large dependence on stock prices. Therefore, it's necessary and innovative to establish a comprehensive evaluation model of production, Sales and R \& D synergistic effect after M\&A.

\section{Index System of Production, Sales and R \& D Synergistic Effect}

\section{Index Selection}

After the interview and investigation of six enterprises and some experts, indexes of production, sales and R \& D synergy were picked. Then questionnaire survey was adopted to select indexes from production synergy, sales synergy and R\&D synergy aspects. The following is the questionnaire result of experts' opinion about the importance sequence of evaluation indexes.

Tab.1 The Importance Sequence of Indexes

\begin{tabular}{|c|c|c|c|c|}
\hline Dimension & Positive synergy index & Weight & Negative synergy index & Weight \\
\hline \multirow{7}{*}{ Production synergy } & Qualified rate & $90.36 \%$ & Risk of organizational culture clash & $72.69 \%$ \\
\hline & Productivity & $85.45 \%$ & Values conflict risk & $83.54 \%$ \\
\hline & $\begin{array}{l}\text { Rate of production cost } \\
\text { reduction }\end{array}$ & $82.00 \%$ & Legal risk & $40.56 \%$ \\
\hline & $\begin{array}{c}\text { Information technology } \\
\text { advancement }\end{array}$ & $30.12 \%$ & Technical risks & $86.00 \%$ \\
\hline & Employee satisfaction & $81.45 \%$ & Ethical and moral risks & $78.96 \%$ \\
\hline & $\begin{array}{l}\text { Social environmental } \\
\text { friendliness }\end{array}$ & $87.65 \%$ & Loss of property risks & $83.64 \%$ \\
\hline & Technical advancement & $76.75 \%$ & & \\
\hline \multirow{9}{*}{ Sales synergy } & Production sales rate & $89.34 \%$ & Risk of organizational culture clash & $83.55 \%$ \\
\hline & Employee satisfaction & $65.35 \%$ & Values conflict risk & $69.56 \%$ \\
\hline & $\begin{array}{l}\text { Logistics and warehousing } \\
\text { efficiency }\end{array}$ & $68.54 \%$ & Legal risk & $81.46 \%$ \\
\hline & Customer Satisfaction & $90.50 \%$ & Technical risks & $50.85 \%$ \\
\hline & Information degree & $46.58 \%$ & Ethical and moral risks & $70.24 \%$ \\
\hline & Advertising promotion & $82.65 \%$ & Loss of property risks & $30.58 \%$ \\
\hline & Frequency of joint activity & $20.56 \%$ & & \\
\hline & Brand extension & $20.56 \%$ & & \\
\hline & Rate of sales cost reduction & $80.56 \%$ & & \\
\hline \multirow{6}{*}{ R\&D synergy } & Processing information ability & $40.25 \%$ & Risk of organizational culture clash & $91.56 \%$ \\
\hline & Employee satisfaction & $50.86 \%$ & Values conflict risk & $83.17 \%$ \\
\hline & Technical advancement & $86.56 \%$ & Legal risk & $78.62 \%$ \\
\hline & $\mathrm{R} \& \mathrm{D}$ process rationality & $86.52 \%$ & Technical risks & $89.43 \%$ \\
\hline & $\begin{array}{c}\text { Rate of new production } \\
\text { developing }\end{array}$ & $91.36 \%$ & Ethical and moral risks & $83.46 \%$ \\
\hline & Rate of $\mathrm{R} \& \mathrm{D}$ cost reduction & $82.45 \%$ & Loss of property risks & $75.35 \%$ \\
\hline
\end{tabular}

\section{Index System Establishing}

After the importance sequencing, index with the least importance was eliminated. And the other indexes were appraised with Likert scale and 1-10 points methods form the positive and negative synergistic effect of production, sales and $R \& D$ respects.

The content of scoring criteria is given as following: 
Tab.2 Production, Sales and R\&D Synergy Effect Evaluation System

\begin{tabular}{|c|c|c|c|c|c|c|}
\hline \multicolumn{7}{|c|}{ Positive synergy effect evaluation system } \\
\hline \multirow[b]{2}{*}{$\begin{array}{l}\text { First-class } \\
\text { indicators }\end{array}$} & \multirow[b]{2}{*}{ Second-class indicators } & \multicolumn{5}{|c|}{ Criteria } \\
\hline & & 10-9[point & 8-7[point] & $6-5$ [point] & 4-3[point] & $2-1$ [point] \\
\hline \multirow{6}{*}{$\begin{array}{l}\text { Production } \\
\text { positive } \\
\text { synergy } \\
\text { effect }\end{array}$} & Qualified rate & $\begin{array}{l}\text { Strongly } \\
\text { high }\end{array}$ & High & $\begin{array}{l}\text { Neither high nor } \\
\text { low }\end{array}$ & Low & Strongly low \\
\hline & Productivity & $\begin{array}{l}\text { Strongly } \\
\text { high }\end{array}$ & High & $\begin{array}{c}\text { Neither high nor } \\
\text { low }\end{array}$ & Low & Strongly low \\
\hline & $\begin{array}{l}\text { Rate of production cost } \\
\text { reduction }\end{array}$ & $\begin{array}{l}\text { Strongly } \\
\text { high }\end{array}$ & High & $\begin{array}{c}\text { Neither high nor } \\
\text { low }\end{array}$ & Low & Strongly low \\
\hline & Employee satisfaction & $\begin{array}{l}\text { Strongly } \\
\text { satisfied }\end{array}$ & Satisfied & $\begin{array}{c}\text { Neither satisfied nor } \\
\text { unsatisfied }\end{array}$ & Unsatisfied & $\begin{array}{c}\text { Strongly } \\
\text { unsatisfied }\end{array}$ \\
\hline & $\begin{array}{l}\text { Social environmental } \\
\text { friendliness }\end{array}$ & $\begin{array}{l}\text { Strongly } \\
\text { friendly }\end{array}$ & Friendly & $\begin{array}{l}\text { Neither friendly nor } \\
\text { unfriendly }\end{array}$ & Unfriendly & $\begin{array}{c}\text { Strongly } \\
\text { unfriendly }\end{array}$ \\
\hline & Technical advancement & $\begin{array}{l}\text { Strongly } \\
\text { advanced }\end{array}$ & Advanced & $\begin{array}{l}\text { Neither advanced } \\
\text { nor backward }\end{array}$ & Backward & $\begin{array}{c}\text { Strongly } \\
\text { backward }\end{array}$ \\
\hline \multirow{7}{*}{$\begin{array}{c}\text { Sales } \\
\text { positive } \\
\text { synergy } \\
\text { effect }\end{array}$} & Production sales rate & $\begin{array}{l}\text { Strongly } \\
\text { high }\end{array}$ & High & $\begin{array}{c}\text { Neither high nor } \\
\text { low }\end{array}$ & Low & Strongly low \\
\hline & Employee satisfaction & $\begin{array}{l}\text { Strongly } \\
\text { satisfied }\end{array}$ & Satisfied & $\begin{array}{c}\text { Neither satisfied nor } \\
\text { unsatisfied }\end{array}$ & Unsatisfied & $\begin{array}{l}\text { Strongly } \\
\text { unsatisfied }\end{array}$ \\
\hline & $\begin{array}{c}\text { Logistics and } \\
\text { warehousing efficiency }\end{array}$ & $\begin{array}{l}\text { Strongly } \\
\text { high }\end{array}$ & High & $\begin{array}{c}\text { Neither high nor } \\
\text { low }\end{array}$ & Low & Strongly low \\
\hline & Customer Satisfaction & $\begin{array}{l}\text { Strongly } \\
\text { satisfied }\end{array}$ & Satisfied & $\begin{array}{c}\text { Neither satisfied nor } \\
\text { unsatisfied }\end{array}$ & Unsatisfied & $\begin{array}{c}\text { Strongly } \\
\text { unsatisfied }\end{array}$ \\
\hline & Information degree & $\begin{array}{l}\text { Strongly } \\
\text { high }\end{array}$ & High & $\begin{array}{c}\text { Neither high nor } \\
\text { low }\end{array}$ & Low & Strongly low \\
\hline & Advertising promotion & $\begin{array}{l}\text { Strongly } \\
\text { high }\end{array}$ & High & $\begin{array}{c}\text { Neither high nor } \\
\text { low }\end{array}$ & Low & Strongly low \\
\hline & $\begin{array}{l}\text { Rate of sales cost } \\
\text { reduction }\end{array}$ & $\begin{array}{l}\text { Strongly } \\
\text { high }\end{array}$ & High & $\begin{array}{c}\text { Neither high nor } \\
\text { low }\end{array}$ & Low & Strongly low \\
\hline \multirow{5}{*}{$\begin{array}{c}\text { R\&D } \\
\text { positive } \\
\text { synergy } \\
\text { effect }\end{array}$} & Employee satisfaction & $\begin{array}{l}\text { Strongly } \\
\text { satisfied }\end{array}$ & Satisfied & $\begin{array}{c}\text { Neither satisfied nor } \\
\text { unsatisfied }\end{array}$ & Unsatisfied & $\begin{array}{c}\text { Strongly } \\
\text { unsatisfied }\end{array}$ \\
\hline & Technical advancement & $\begin{array}{c}\text { Strongly } \\
\text { advanced }\end{array}$ & Advanced & $\begin{array}{c}\text { Neither advanced } \\
\text { nor backward }\end{array}$ & Backward & $\begin{array}{c}\text { Strongly } \\
\text { backward }\end{array}$ \\
\hline & $\mathrm{R} \& \mathrm{D}$ process rationality & $\begin{array}{l}\text { Strongly } \\
\text { rational }\end{array}$ & rational & $\begin{array}{l}\text { Neither rational nor } \\
\text { irrational }\end{array}$ & Irrational & $\begin{array}{l}\text { Strongly } \\
\text { irrational }\end{array}$ \\
\hline & $\begin{array}{c}\text { Rate of new production } \\
\text { developing }\end{array}$ & $\begin{array}{l}\text { Strongly } \\
\text { high }\end{array}$ & High & $\begin{array}{l}\text { Neither high nor } \\
\text { low }\end{array}$ & Low & Strongly low \\
\hline & $\begin{array}{l}\text { Rate of } R \& D \text { cost } \\
\text { reduction }\end{array}$ & \begin{tabular}{c|c}
$\begin{array}{c}\text { Strongly } \\
\text { high }\end{array}$ & \\
\end{tabular} & High & $\begin{array}{c}\text { Neither high nor } \\
\text { low }\end{array}$ & Low & Strongly low \\
\hline \multicolumn{7}{|c|}{ Negative synergy effect evaluation system } \\
\hline \multirow{2}{*}{$\begin{array}{l}\text { First-class } \\
\text { indicators }\end{array}$} & \multirow{2}{*}{ Second-class indicators } & \multicolumn{5}{|c|}{ Degree of risks } \\
\hline & & \multicolumn{2}{|c|}{ [8-7]point } & [6-5]point & [4-3]point & [2-1]point \\
\hline \multirow{5}{*}{$\begin{array}{l}\text { Production } \\
\text { negative } \\
\text { synergy } \\
\text { effect }\end{array}$} & $\begin{array}{l}\text { Risk of organizational } \\
\text { culture clash }\end{array}$ & Level 1 & Level 2 & Level 3 & Level 4 & Level 5 \\
\hline & Values conflict risk & Level 1 & Level 2 & Level 3 & Level 4 & Level 5 \\
\hline & Technical risks & Level 1 & Level 2 & Level 3 & Level 4 & Level 5 \\
\hline & Ethical and moral risks & Level 1 & Level 2 & Level 3 & Level 4 & Level 5 \\
\hline & Loss of property risks & Level 1 & Level 2 & Level 3 & Level 4 & Level 5 \\
\hline \multirow{5}{*}{$\begin{array}{c}\text { Sales } \\
\text { negative } \\
\text { synergy } \\
\text { effect }\end{array}$} & $\begin{array}{c}\text { Risk of organizational } \\
\text { culture clash }\end{array}$ & Level 1 & Level 2 & Level 3 & Level 4 & Level 5 \\
\hline & Values conflict risk & Level 1 & Level 2 & Level 3 & Level 4 & Level 5 \\
\hline & Legal risk & Level 1 & Level 2 & Level 3 & Level 4 & Level 5 \\
\hline & Technical risks & Level 1 & Level 2 & Level 3 & Level 4 & Level 5 \\
\hline & Ethical and moral risks & Level 1 & Level 2 & Level 3 & Level 4 & Level 5 \\
\hline \multirow{5}{*}{$\begin{array}{c}\text { R\&D } \\
\text { negative } \\
\text { synergy } \\
\text { effect }\end{array}$} & $\begin{array}{l}\text { Risk of organizational } \\
\text { culture clash }\end{array}$ & Level 1 & Level 2 & Level 3 & Level 4 & Level 5 \\
\hline & Values conflict risk & Level 1 & Level & Level 3 & Level 4 & Level 5 \\
\hline & Legal risk & Level 1 & Level & Level 3 & Level 4 & Level 5 \\
\hline & Technical risks & Level 1 & Level & Level 3 & Level 4 & Level 5 \\
\hline & Ethical and moral risks & Level 1 & Level & Level 3 & Level 4 & Level 5 \\
\hline
\end{tabular}

As shown in table 2, the index system is composed of 6 primary indexes, 34 secondary indexes and scoring criteria. And the index system has some advantages: First, the index system is integral. 
Enterprises can know both advantages and disadvantages. Second, the system use much more non-financial indexes indicating that enterprises should also pay attention to social responsibility and long-term development. It is more scientific and rational. Third, Likert five-scale method is used to estimate some qualitative indexes. It's more accurate.

\section{Index Weight}

As for the index weight, there are many methods to calculate it in existing literatures, like 0-1 method (forced decision), multi-proportional scoring, DARE method, experts scoring, analytic hierarchy process (AHP), etc. These calculation methods are affected by subjective factors in varying degrees. The scientificity and rationality of calculation results can't be guaranteed without a hierarchical index system. In consequence, experts scoring and AHP method are used to calculate the weight. It can reduce the influence of subjective factors and help establish a hierarchical, integral and accurate index system.

\section{Production, Sales and R\&D Synergy Effect Evaluation Model}

According analysis, a PAN model was established to evaluate production, sales and R\&D synergistic effect after M\&A from positive synergistic effect and negative synergistic effect. And PAN model is named by the initials of positive and negative.

\section{Model Building}

PAN model is meaningful, which considers enterprise risk and the prospects for business development.

$$
\begin{aligned}
& \text { PAN=Effects of positive synergy/Effects of negative synergy }=\mathrm{P} / \mathrm{N} \\
& =\left(\mathrm{M}_{1} \times \mathrm{P}_{1}+\mathrm{M}_{2} \times \mathrm{P}_{2}+\mathrm{M}_{3} \times \mathrm{P}_{3}\right) /\left(\mathrm{R}_{1} \times \mathrm{N}_{1}+\mathrm{R}_{2} \times \mathrm{N}_{2}+\mathrm{R}_{3} \times \mathrm{N}_{3}\right)
\end{aligned}
$$

In the formula 1, PAN is enterprise production, sales and R\&D synergy effect Effects of positive synergy:

$$
\mathrm{P}=\mathrm{M}_{1} \times \mathrm{P}_{1}+\mathrm{M}_{2} \times \mathrm{P}_{2}+\mathrm{M}_{3} \times \mathrm{P}_{3}, \mathrm{M}_{1}+\mathrm{M}_{2}+\mathrm{M}_{3}=1
$$

$\mathrm{P}_{1}$ : Production positive synergistic effect

$\mathrm{P}_{2}: \mathrm{R} \& \mathrm{D}$ positive synergistic effect

$\mathrm{P}_{3}$ : Sales positive synergistic effect

$\mathrm{M}_{1}$ : Weight of production positive synergistic effect

$\mathrm{M}_{2}$ : Weight of R\&D positive synergistic effect

$\mathrm{M}_{3}$ : Weight of sales positive synergistic effect

Effects of negative synergy:

$$
\mathrm{R}=\mathrm{R}_{1} \times \mathrm{N}_{1}+\mathrm{R}_{2} \times \mathrm{N}_{2}+\mathrm{R}_{3} \times \mathrm{N}_{3}, \mathrm{R}_{1}+\mathrm{R}_{2}+\mathrm{R}_{3}=1
$$

$\mathrm{N}_{1}$ : Production negative synergistic effect

$\mathrm{N}_{2}: R \& D$ negative synergistic effect

$\mathrm{N}_{3}$ : Sales negative synergistic effect

$\mathrm{R}_{1}$ : Weight of production negative synergistic effect

$R_{2}$ : Weight of $R \& D$ negative synergistic effect

$\mathrm{R}_{3}$ : Weight of sales negative synergistic effect

\section{Explaining of Evaluation Model Result}

According to formula 1, the result of PAN model is the ratio of positive synergistic effect and negative synergistic effect. And the result has 3 cases.

(1) PAN >1. It means that positive synergistic effect is greater than negative synergistic effect 
after merger. And the enterprise is in good development. (2) PAN=1. It means that positive synergistic effect is same as negative synergistic effect after merger. So the enterprise should take some measures for better developing in this period. (3) PAN $<1$. It means that positive synergistic effect is less than negative synergistic effect after merger. It usually happens at the beginning or end of production, sales and R\&D synergy. At the beginning of synergy, each department needs to take time to coordinate and run, so some mistakes are unavoidable. At the end of synergy, existing cooperative mode can't vary with the changing of enterprise's needs.

\section{Conclusion}

After researching the existing literatures, the author innovatively established an evaluation model of production, sales and R\&D synergistic effect from the positive and negative synergistic effect aspects. 6 primary indexes and 34 secondary indexes were selected with the method of questionnaire survey. Then AHP method and experts scoring are adopted to design the scoring criteria and calculate the weight. Finally a practical evaluation model named PAN was established to evaluate the production, sales and R\&D synergistic effect. In the meantime, this evaluation model also has some defects. The author only did investigation for several enterprises and interviewed some experts when selecting index. The evaluation model of production, sales and $\mathrm{R} \& \mathrm{D}$ synergistic effect may not be suitable for all industries and enterprises. Further empirical research about the universality of the evaluation model is needed.

\section{Acknowledgement}

This research was financially supported by Research Project of Humanities and Social Sciences in the Education Department of Hubei Province and Graduate Student Education Research Project of Wuhan University of Science and Technology.

\section{References}

[1] Q.B. BAI, Research on the establishment and evaluation of enterprise synergistic capability in collaborative business environment, D. Yunnan University of Finance and Economics. 2009.

[2]M Bradley, A Desai, Synergistic gains from corporate acquisitions and their division between the stockholders of target and acquiring firms, J. Journal of financial Economics.2010,18(4) 16-19.

[3] J.C, Y.J. Yang, Driven Mechanism of Collaborative Innovation, J. Technology Economics. 2012, 31(8) 6-11.

[4] H Igor Ansoff, Corporate Strategy: An Analytic Approach to Business Policy for Growth and Expansion [M]. New York, 2010.

[5] Itami Hiroyuki, Mobilizing Invisible Assets, Boston, Harvard University Press, 1987, 253-257.

[6] ZQ. FENG, Study on Enterprise Group Controlling Mechanism based on Financial Cooperation, J. Techno-economics \& Management Research. 2013(6) 53-57.

[7] W.G.LIU, L.S.WANG, L.B.SUN, Analysis of Intangible Resources Transference in Transnational Corporate M\&A, J. China Industrial Economy. 2007(3) 120-128.

[8] L.Y.Yang, Research on Influence Factors of Supply Chain Enterprises' Collaborative Effect, J. China Market. 2011(15) 55-56.

[9] William E Baker, Synergistic Effect of Market Orientation and Learning Orientation on Organizational Performance, J. Marketing Science.2009, 54(9) 89-92.

[10] X.F.WANG, Study on Evaluation Model and Methods of collaborative products' developing capabilities, J. Science \& Technology Progress and Policy. 2010, 27(6) 136-138. 